\title{
ANALISIS PEMASARAN SUSU KEDELAI PADA HOME INDUSTRI DI DESA \\ PAUH MENANG KECAMATAN PAMENANG KABUPATEN MERANGIN \\ ( Studi Kasus Susu Kedelai Suka Rasa Pak Bakrun )
}

\section{MARKETING ANALYSIS OF SOYBEAN MILK IN HOME INDUSTRY IN PAUH WIN \\ VILLAGE, PAMENANG DISTRICT \\ MERANGIN DISTRICT}

(Case Study Soy Milk Likes Pak Bakrun's Flavor)

\author{
Asnawati Is, Sykhafudin, Setiono \\ Program Studi Agribisnis, Fakultas Pertanian, Universitas Muara Bungo, Jl.Pendidikan, \\ RT.10 RW.02 No.10 Kelurahan Sungai Binjai Kecamatan Bathin III. Kabupaten Bungo, \\ Jambi 372238, Indonesia. \\ zahira_siregar@yahoo.co.id, tiosetiono18@gmail.com
}

\begin{abstract}
ABSTRAK
Tujuan dari penelitian ini adalah untuk mengetahui pola/saluran pemasaran dan fungsi-fungsi pemasaran yang dilakukan tiap lembaga pemasaran susu kedelai dengan menganalisis tingkat efisiensi pemasaran yang diterima masing-masing lembaga pemasaran susu kedelai suka rasa di Desa Pauh Menang Kecamatan Pamenang Kabupaten Merangin.

Dalam penelitian ini metode penentuan responden adalah dengan metode studi kasus (Case Study) dimana penelitian dipusatkan pada obyek tertentu dan kesimpulan diambil hanya berlaku terbatas pada objek yang diteliti. Yaitu industri susu kedelai suka rasa di Desa Pauh Menang Kecamatan Pamenang Kabupaten Merangin. Sedangkan untuk analisis data yang digunakan dalam penelitian ini meliputi analisis pola pemasaran, fungsi-fungsi pemasaran dan efisiensi pemasaran.

Hasil penelitian ini menunjukkan saluran pemasaran susu kedelai suka rasa di Desa Pauh Menang Kecamatan Pamenang Kabupaten Merangin terdiri dari 3 pola pemasaran yaitu pola I: produsen- konsumen, Pola II: produsen - pengecer - konsumen pada pola III: produsen - grosir - pengecer - konsumen. Pada fungsi pemasaran yang di lakukan lembaga pemasaran susu kedelai suka rasa meliputi fungsi pertukaran, fungsi fisik, dan fungsi fasilitas. Ketiga saluran pemasaran susu kedelai suka rasa di Desa Pauh Menang Kecamatan Pamenang Kabupaten Merangin sudah efisien karena pada saluran I bersifat efisien dengan Nilai Farmer's share 100\% saluran II bersifat efisien dengan Nilai Farmer's share 60\%, dan padasaluran III juga bersifat efisien dengan Nilai Farmer's share 50\%.
\end{abstract}

Kata Kunci : Pola dan Saluran Pemasaran, Fungsi Pemasaran, Efisiensi Pemasaran, Susu Kedelai

\section{ABSTRACT}

The purpose of this study was to determine the marketing patterns/channels and marketing functions performed by each marketing agency for soy milk by analyzing the level of marketing efficiency received by each marketing agency for flavored soy milk in Pauh Menang Village, Pamenang District, Merangin Regency.

In this research, the method of determining respondents is the case study method, where the research is focused on a particular object and conclusions are drawn only limited to the object under study. Namely, the flavored soy milk industry in Pauh Menang Village, 
Pamenang District, Merangin Regency. Meanwhile, the data analysis used in this research includes the analysis of marketing patterns, marketing functions and marketing efficiency.

The results of this study indicate that the marketing channel of flavored soy milk in Pauh Menang Village, Pamenang District, Merangin Regency consists of 3 marketing patterns, namely pattern I: producer-consumer, Pattern II: producer - retailer - consumer in pattern III: producer - wholesaler - retailer - consumer. The marketing functions carried out by the marketing agency for flavored soy milk include exchange functions, physical functions, and facility functions. The three marketing channels for flavored soy milk in Pauh Menang Village, Pamenang District, Merangin Regency are efficient because channel I is efficient with a Farmer's share value of 100\%, channel II is efficient with a Farmer's share value of 60\%, and channel III is also efficient with a Farmer's share value. 50\%.

Keywords: Marketing Patterns and Channels, Marketing Functions, Marketing Efficiency, Soy Milk

\section{Pendahuluan}

Pertanian merupakan salah satu sektor yang sangat penting dalam perekonomian nasional. Oleh karena itu, maka sektor itu harus mampu dibangun menjadi andalan dan sebagai mesin penggerak perekonomian nasional. Salah satu upaya yang dapat dilakukan adalah mengoptimalkan pemanfaatan sumberdaya domestik (lahan, air, tenaga kerja, modal, dan teknologi), sehingga memberikan peningkatan kesejahteraan petani dan masyarakat konsumen secara berimbang (Solahuddin, 2011).

Pada dasarnya Sektor Pertanian mempunyai peranan yang sangat besar dalam pertumbuhan ekonomi negara terutama negara yang bercorak agraris seperti Indonesia. Pembangunan ekonomi menitik beratkan pada bidang pertanian dan industri yang berbasis pertanian atau biasa disebut agroindustri. Dalam sistem agribisnis, agroindustri adalah salah satu subsistem yang bersama-sama subsistem lain membentuk agribisnis. sektor pertanian yang baik maka hal ini juga akan berdampak baik bagi daerah pedesaan karena sektor pertanian merupakan sektor yang sangat berpengaruh bagi daerah pedesaan dalam hal untuk mendapatkan pendapatan riil pedesaan. Jika sektor pertanian yang ada di desa dapat terus maju dan berkembang maka pendapatan riil pedesaan juga pasti akan naik (Fikriman. 2017).Sistem agribisnis terdiri dari subsistem Input, usahatani, sistem
Output, pemasaran dan penunjang, dengan demikian pembangunan agroindustri tidak dapat dilepaskan dari pembangunan agribisnis secara keseluruhan. Pembangunan agroindustri akan dapat meningkatkan produksi, harga hasil pertanian, Pendapatan Petani, serta dapat menghasilkan nilai tambah hasil Pertanian (Mashyuri, 1994).

Industrialisasi pertanian dike-nal dengan nama agroindustri, dimana agroindustri dapat menjadi salah satu pilihan strategis dalam menghadapi masalah dalam upaya peningkatan perekonomian masyarakat dipedesaan serta mampu menciptakan kesempa-tan kerja bagi masyarakat yang hidup dipedesaan, sektor industri pertanian merupakan suatu sistem pengelolaan secara terpadu antara sektor pertanian dengan sektor industri guna menda-patkan nilai tambah dari hasil perta-nian, agroindustri merupakan usaha untuk meningkatkan efisiensi sektor pertanian hingga menjadi kegiatan yang sangat produktif melalui proses modernisasi pertanian. Modernisasi di sektor industri dalam skala nasional dapat mening-katkan penerimaan nilai tambah sehingga pendapatan ekspor akan lebih besar (Yorin. 2009).

Adanya industri pengolahan akan membuat hasil pertanian menja-di suatu produk yang mempunyai nilai tambah dan bernilai ekonomi yang tinggi, sehingga mampu me-ningkatkan pendapatan atau 
meraih keuntungan. Keuntungan agroindustri olahan kedelai merupakan selisih antara besarnya jumlah nilai penerimaan dengan besarnya jumlah biaya produksi yang dikeluarkan. Besarnya keuntungan yang diterima dapat digunakan sebagai tolok ukur dalam melihat perkembangan agroindustri olahan kedelai tersebut dalam jangka panjang. Selanjutnya industri olahan kedelai skala kecil dapat ikut memperluas lapangan kerja. dengan sasaran akhir dapat memberikan dam-pak dan kontribusi dari agroindustri olahan kedelai secara langsung mau-pun secara tidak langsung terhadap perekonomian nasional.

Kedelai merupakan salah satu komoditas pangan. Kedelai meru-pakan bahan makanan yang mempu-nyai nilai gizi cukup tinggi. Di antara jenis kacangkacangan, kedelai meru-pakan sumber protein, lemak, vita-min, mineral dan serat yang paling baik. Di dalam lemak kedelai terkandung beberapa fosfoli-pida penting, yaitu lestin, sepalin, dan lipositol (Cahyadi, 2012).

Melihat kepopuleran tanaman kedelai dan khasiatnya bagi tubuh dan kesehatan manusia, maka tidaklah aneh jika begitu banyak makanan olahan dari kedelai yang beredar di sejumlah toko dan supermarket, seperti tauco, kembang tahu dan lain-lain. Meski masyarakat sejak lama terbiasa mengkonsumsi makanan dari kedelai, namun masih banyak yang belum mengetahui dan menyadari bahwa kedelai memiliki kegunaan yang sangat banyak. Jika dicermati dengan seksama, ternyata tanaman kedelai mampu mengha-silkan sejumlah produk makanan atau minuman tertentu (Cahyadi, 2012).

Produk makanan yang dibuat dari bahan baku kedelai diantaranya adalah susu kedelai seperti susu sapi yang dibuat dari ekstrak kedelai. Kadar protein dan komposisi asam amino serta lemak dalam susu kedelai hampir sama dengan susu sapi, dimana komposisinya tergantung pada varietas kedelai dan cara pengolahannya. Kedelai yang bisa kita peroleh dalam bentuk tempe, tahu dan susu, selain mengandung protein juga mengandung zat besi, kalsium, vitamin A, B, B1, dan B2 yang lebih banyak dibandingkan dengan jenis kacang lainnya (Cahyadi, 2012).

Kedelai biasanya sering dikonsumsi oleh manusia sebagai bahan makanan pokok atau sebagai bahan olahan pangan dalam prospek perindustrian yang ingin dijalankan, Perkembangan luas panen dan produksi kedelai di kabupaten Merangin yang tertinggi berda pada Kecamatan Pamenang yang dimana Kecamatan Pamenang itu sendiri adalah tempat berdirinya Home Industri susu kedelai yang saya teliti.

Kabupaten Merangin memili-ki Produksi Kedelai sebnyak 1.929 ton dengan luas lahan 1.541 Ha yang tersebar di 24 Kecamatan, dan hanya 1 Kecamatan yang tidak mempro-duksi kedelai, kecamatan yang tidak memproduksi kedelai adalah Keca-matan Bangko. berdasarkan data Dinas Tanaman Pangan dan Hortikul-tura Kabupaten Merangin (2018), menunjukan bahwa Produksi kedelai di Kecamatan Pamenang sebesar 371 ton dalam luas lahan $294 \mathrm{Ha}$, yang menduduki posisi pertama terbesar diantara seluruh kecamatan yang ada di Kabupaten Merangin, dengan total produksi nya sebesar 1.929 ton dalam luas lahan $1.541 \mathrm{Ha}$.

Produksi kedelai di Kecama-tan Pamenang dari tahun ke tahun mengalami ketidak stabilan ataupun terjadi penurunan, penurunan terjadi pada tahun 2014 ke 2015 sebesar 41 ton dan pada tahun 2018 terjadi peningkatan dan merupakan produksi yang paling besar diantara tahun ke tahunnya yaitu sebesar 371 ton.

Salah satu industri yang saat ini sedang dikembangkan di Kecam-atan Pamenang pada pengolahan kedelai yaitu sebagai bahan baku susu kedelai, yaitu usaha yang bernama susu kedelai suka rasa di Desa Pauh Menang Kecamatan Pamenang merupakan satu-satunya usaha susu kedelai di Desa Pauh Menang Kecamatan Pamenang, usaha susu kedelai 
ini diberi nama susu kedelai suka rasa yang berdiri pada tahun 2010 dan dikelola oleh Pak Bakrun dan keluarganya, sejak berdiri dari tahun 2010 usaha susu kedelai ini sempat mengalami kesulitan dalam hal pemasaran kesulitan itu terjadi pada tahun pertama berdirinya home industri susu kedelai ini, namun Pak Bakrun tidak berhenti memproduksi susu kedelai untuk di pasarkannya, memasuki tahun ke 2 home industri Pak Bakrun mulai dikenal masyarakat terutama masyarakat Kecamatan Pamenang hingga saat ini Pak Bakrun terus memproduksi susu kedelai dengan bahan kedelai mentah $16 \mathrm{~kg}$ perharinya.

Dapat dilihat dari perkem-bangan usahanya, Home Industri susu kedelai suka rasa berproduksi hampir setiap hari. Peningkatan nilai tambah yang dilakukan meliputi pengemba-ngan produk dan sampai saat ini Home Industri susu kedelai suka rasa mampu memproduksi dalam bentuk kemasan dengan jumlah prduksi yang lumayan besar. dengan jumlah permintaan susu kedelai yang cukup banyak, maka akan menciptakan sebuah rantai saluran pemasaran.

Tujuan yang akan jadi sasaran bagi penelitian ini adalah : untuk mengetahui pola pemasaran, fungsi-fungsi pemasaran dan efisi-ensi pemasaran susu kedelai pada Home Industri Suka Rasa Didesa Pauh Menang Kecamatan Pamenang Kabupaten Merangin.

Berdasarkan survey awal yang dilakukan pada home industri susu kedelai suka rasa yang berproduksi setiap hari dengan memproduksi $16 \mathrm{~kg}$ kedelai setiap harinya, dengan jumlah permintaan yang cukup banyak permintaan susu kedelai ini mencakup warga sekitar dan beberapa pedagang grosir di berbagai Kecamatan di Kabupaten Merangin, hal ini tentu menciptakan rantai pemasaran sehingga pemasa-ran susu kedelai pada home indsutri suka rasa ini menarik untuk di teliti lebih lanjut. Karena dengan terjaminnya pemasaran akan meningkatnya produksi industri yang di jalankan serta memperlancar sebuah industri yang di jalankan.

Berdasarkan uraian di atas, penulis tertarik untuk melakukan penelitian dengan judul "Analisis Pemasaran Susu Kedelai Pada Home Industri Suka Rasa Di Desa Pauh Menang Kecamatan Pamenang Kabupaten Merangin (Studi Kasus Susu Kedelai Suka Rasa Pak Bakrun)"

\section{Metodologi Penelitian}

Penelitian ini dilaksanakan di Home Industri susu kedelai suka rasa Desa Pauh Menang Kecamatan Pamenang Kabupaten Merangin. Pemilihan lokasi dilakukan secara sengaja (Purposive). Dikarenakan usaha Home Industri Susu Kedelai yang di jalankan oleh Pak Bakrun ini merupakan Produksi yang terbesar Produksinya di Kabupaten Merangin (Dinas Perindustrian Kabupaten Merangin 2017) Penelitian ini dilaksanakan pada tanggal 1 Maret s/d 30 Maret 2020.

Adapun jenis data yang digunakan dalam penelitian ini adalah data primer dan data sekunder. Data primer dalam penelitian ini diperoleh secara langsung dari objek penelitian yang diamati. Metode penelitian yang digunakan untuk menggali data dan informasi di lapangan adalah pende-katan deskriptif. Data yang digunakan dalam penelitian ini adalah data kuantitatif yang didukung oleh data kualitatif, hal ini dilakukan untuk mendapatkan hasil yang kuat dan akurat. Data kuantitatif dikumpulkan dengan metode survey. Menurut Sugiyono (2013) pengertian metode survey adalah Penelitian yang dilakukan dengan menggunakan angket sebagai alat penelitian yang dilakukan pada populasi besar maupun kecil, tetapi data yang dipelajari adalah data dari sampel yang diambil dari populasi tersebut, sehingga ditemukan kejadian relatif, distribusi, dan hubungan antar variabel, sosiologis maupun psikolo-gis. Data kualitatif sebagai pendukung penelitian untuk mengetahui gamba-ran umum serta lokasi penelitian. 
Dalam penelitian ini metode penentuan responden adalah dengan metode studi kasus (Case Study) dimana penelitian dipusatkan pada obyek tertentu dan kesimpulan diambil hanya berlaku terbatas pada objek yang diteliti. Dalam penelitian ini yang menjadi responden adalah Industri Rumah Tangga susu kedelai suka rasa di Desa Pauh Menang Kecamatan Pamenang Kabupaten Merangin Provinsi Jambi.

\section{Metode Analisis Data}

Analisis pengolahan data secara kuantitatif dan kualitatif kemudian di jelaskan secara deskriptif. Analisis dilakukan dengan memasukan data primer yang telah di olah ke dalam tabel yang telah disiapkan. Baik data primer dan skunder yang diperoleh dari hasil penelitian akan di tabulasikan dan di tampilkan dalam tabel dan gambar setelah di olah sesuai dengan kebutu-han data. Analisis dalam penelitian ini meliputi analisis saluran pemasaran dan efisiensi pemasaran susu kedelai pada home industri suka rasa.

\section{Analisis Pola Pemasaran}

Pola pemasaran akan di analisis secara kualitatif dengan mengamati lembaga pemasaran yang terlibat dalam pemasaran susu kedelai mulai dari Produsen hingga ke Konsumen akhir. Lembaga pema-saran ini berperan sebagai perantara dalam menyampaikan barang dari produsen ke konsumen dan arus barang yang melalui lembaga-lemba-ga yang menjadi perantara memben-tuk saluran pemasaran.

\section{- Analisis Fungsi-Fungsi Pema-saran}

Untuk melihat analisis fungsifungsi pemasaran peneliti menggu-nakan cara deskriptif atau mewawancarai responden untuk mengetahui apakah home industri susu kedelai menggunakan fungsifungsi pemasaran.
Analisis Marjin Pemasaran

a) Margin tiap Lembaga pemasaran Susu Kedelai

$\mathrm{Mp}=\frac{\operatorname{Pr}-\mathrm{pf}}{\operatorname{Pr}} \mathrm{X} 100 \%$

Dimana :

$\mathrm{Mp}=$ Persen Marjin Pemasa-ran

$\operatorname{Pr}=$ Harga ditingkat konsumen akhir (Rp/ bungkus)

Pf = Harga Penjualan Susu Kedelai (Rp/bungkus)

b) Margin tiap saluran Pemasa-ran (Swastha, 1991)

$\mathrm{Mt}=\mathrm{M} 1+\mathrm{M} 2 \ldots \ldots \ldots+\mathrm{Mn}$

Dimana :

Mt = Margin Saluran Pema-saran

M1 = Margin pemasaran lembaga Pemasaran ke-1

M2 = Margin Pemasaran lembaga pemasaran ke2)

Mn $=$ Margin Pemasaran Lem-baga Pemasaran ke-n)

\section{- Farmer's share}

Besarnya harga yang diterima Home Industri Suka Rasa terhadap Konsumen Akhir, dilakuakan dengan farmer's share yang di rumuskan sebagai berikut:

$\mathrm{FS}=\frac{\mathrm{P}}{\mathrm{K}} \mathrm{X} 100$

Dimana :

FS = Pemasaran Susu Kedelai $(\mathrm{Rp})$

$\mathrm{P}=$ Harga ditingkat produsen

$\mathrm{K}=$ Harga yang di bayar konsumen

Jika Fs $<50 \%$ maka pemasaran tidak efisien

Jika Fs $\geq 50 \%$ maka pemasaran efisien (Farida, 1986).

\section{Efesiensi Pemasaran}

Untuk mengetahui tingkat efesiensi pemasaran tiap saluran pemasaran dengan menggunakan rumus efesiensi pemasaran sebagai berikut:

$\mathrm{EP}=\frac{\text { Biaya Pemasaran }}{\text { Nilai Produk Yang Di Pasarkan }} \times 100 \%$

Jika : $\quad \mathrm{EP}>50 \%=$ Tidak Efisien $\mathrm{EP} \leq 50 \%=$ Efisien 


\section{Hasil dan Pembahasan}

\section{Sejarah Home Industri Susu Kedelai Suka Rasa}

Usaha industri rumahan Susu Kedelai yang didirikan oleh Pak Bakrun dengan keluarganya pada tahun 2010. Industri susu kedelai ini di berinama Suka Rasa, selama 10 tahun berdiri pak bakrun mengalami kendala seperti kenaikan bahan baku, pemasaran susu kedelai dan pada awal-awal berdirinya Home Indusri ini Pak Bakrun sempat kesulitan memasarkan produk susu kedelainya, kesulitanitu terjadi selama 3 bulan awal berdirinya Industri ini, pada saat itu Pak Bakrun tidak menyerah begitu saja beliau terus menjajakan susu kedelai buatannya dan pak bakrun juga memberikan produknya secara gratis kepada konsumen agar konsu-men dapat mencicipi produk susu kedelainya, setelah 3 bulan itu di lalui Pak Bakrun konsumen pun langsung mendatangi rumah Pak Bakrun untuk membeli susu kedelai. Pada awalnya kemasan susu kedelai berisi 200gr namun seiring permintaan dan naiknya bahan baku sekarang isi susu kedelai kemsan ini seberat 150gr dengan harga jual Rp. 1.500/bungkus diharga produsen, produksi susu kedelai ini berproduksi setiap hari., dalam satu hari Pak Bakrun dan istrinya dapat menggiling kedeli sebanyak $16 \mathrm{Kg}$ dari kedelai mentah tersebut menghasilkan 880 bungkus susu kedelai. Pada tahun 2016 Home Industri Pak Bakrun mendapat bantuan alat penggiling kedelai dari Dinas terkait dengan alat itu dapat mempercepat pekerjaan, dalam mem-produksi susu kedelai Pak Bakrun mengerjakannya bersama keluarga Pak Bakrun juga tidak memiliki karyawan tetap, jika permintaan meningkat Pak Bakrun dan istri meminta bantuan kepada Ponakan dan Keluarga besarnya.

\section{Analisis Pola Pemasaran}

Pada dasarnya arus pemasaran (saluran pemasaran) yang terbentuk dalam proses pemasaran sangat beragam, minsalnya: I. produsen berhubungan langsung dengan konsumen akhir, II. Produsen - pengecer - konsumen akhir, III Produsen - grosir - pengecer - konsumen akhir dan IV. Produsen - grosir distributor - pengecer - konsumen akhir (Kotler, 1998).

Pola pemasaran susu kedelai suka rasa yang digunakan Pak Bakrun di Desa Pauh Menang Kecamatan Pamenang Kabupaten Merangin sebagai berikut :

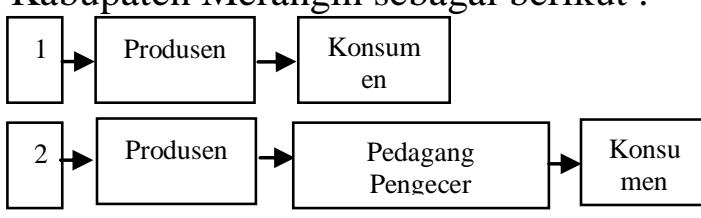

$\begin{aligned} & \text { Gambar 1. } \begin{array}{l}\text { Pola Pedagang } \\ \text { Grosir }\end{array} \\ & \text { Kedelai Suka Rasa di Desa } \\ & \text { Pauh Menang. }\end{aligned}$

Dari gambar diatas, maka terdapat 3 pola saluran pemasaran Susu Kedelai Suka Rasa di Desa Pauh Menang. Terdapat saluran lang-sung, saluran semi langsung, dan saluran tidak langsung. Hal ini sesuai dengan pendapat Mursid, (1997) yang mengemukakan bahwa secara fisik dikenal bahwa terdapat 3 ma-cam penyaluran suatu barang hasil produksi yaitu :

A. Saluran Pemasaran Tingkat I

Pada saluran pemasaran tingkat I, produsen menjual Susu Kedelai langsung. Penjualan ini dengan cara konsumen mendatangi produsen, penjualan ini di lakukan setiap hari, pada saluran pertama produsen tidak mengeluarkan biaya pemasaran, karena konsumen mengambil langsung susu kedelai keprodusen dengan harga jual yaitu Rp. 1.500/bungkus

B. Saluran Pemasaran Tingkat II

Saluran pemasaran tingkat II, produsen menjual produknya secara langsung ke pedagang pengecer yang datang ke produsen, dimana pihak produsen tidak mengantarkan langsung ke tempat-tempat pedagang penegecer melainkan pedagang pengecer yang mengambil ke rumah dengan jumlah yang 
telah disepakati dan harga jual sebesar $\mathrm{Rp}$ $1.500 /$ bungkus.

C. Saluran Pemasaran Tingkat III

Saluran Pemasaran Tingkat III, produsen menjual susu kedelai melalui dua lemabaga pemasaran yaitu Grosir dan pedagang pengecer. Pada saluran ini terlebih dahulu produsen mengabarkan stock susu kedelai yang akan dipasarkan oleh pedagang grosir, dalam hal ini terjadi proses jual beli dengan harga yaitu $\mathrm{Rp}$. 1.500/bungkus, kemudian peda-gang grosir itu menjual kembali susu kedelai kepedagang pengecer, biasanya para pedagang pengencer yang membeli susu kedelai digrosir tersebut adalah para pedagang pengencer yang sudah menjadi langganan dalam membeli susu kedelai yaitu dengan cara menjemput susu kedelai yang sudah distock di grosir. Setelah itu pedagang pengecer menjual susu kedelai ke konsumen sebesar Rp.2.500/bungkus.

\section{Fungsi Pemasaran Susu Kedelai}

Fungsi-fungsi pemasaran adalah segala sesuatu atau tindakan yang dapat melancarkan proses berjalannya suatu pemasaran dari produsen ke konsumen akhir yang meliputi 3 tipe fungsi pemasaran yaitu : 1. Fungsi pertukaran, 2. Fungsi fisik dan 3. Fungsi penye-diaan fasilitas. Kemudian fungsi-fungsi pemasaran tersebut terdiri dari fungsi pertukaran yang meliputi fungsi pejualan dan pembelian, fungsi fisik yang meliputi fungsi penyimpanan, fungsi pengangkutan dan fungsi pengolahan serta fungsi fasilitaas yang meliputi fungsi, fungsi sortasi dan gungsi standa-risasi, pembiayaan, informasi pasar, dan penanggungan resiko (Sudiyono, 2004). Setiap saluran pemasaran melakukan fungsi-fungsi pemasaran dalam memasarkan susu kedelai antara lain fungsi pertukaran, fungsi fisik, dan fungsi fasilitas. Fungsi-fungsi tersebut dapat dlihat pada Tabel 1 sebagai berikut.
Tabel 1. Fungsi-Fungsi Pemasaran Susu Kedelai Suka Rasa Di Desa Pauh Menang Kecamatan Pamenang Kabupaten Merangin.

\begin{tabular}{|c|c|c|c|c|}
\hline $\begin{array}{c}\text { Fungs } \\
\text { i }\end{array}$ & $\begin{array}{l}\text { Aktivit } \\
\text { as }\end{array}$ & $\begin{array}{l}\text { Prod } \\
\text { usen }\end{array}$ & $\begin{array}{l}\text { Peda } \\
\text { gang } \\
\text { grosi } \\
\quad \mathbf{r}\end{array}$ & $\begin{array}{l}\text { Peda } \\
\text { gang } \\
\text { Peng } \\
\text { ecer }\end{array}$ \\
\hline \multirow{4}{*}{$\begin{array}{l}\text { Pertuk } \\
\text { aran } \\
\text { Fisik }\end{array}$} & Jual & $\sqrt{ }$ & $\sqrt{ }$ & $\sqrt{ }$ \\
\hline & Beli & - & $\sqrt{ }$ & $\sqrt{ }$ \\
\hline & Pengang & - & $\sqrt{ }$ & $\sqrt{ }$ \\
\hline & $\begin{array}{l}\text { kutan } \\
\text { Penyim } \\
\text { panan }\end{array}$ & $\sqrt{ }$ & $\sqrt{ }$ & $\sqrt{ }$ \\
\hline \multirow{4}{*}{$\begin{array}{l}\text { Fasilit } \\
\text { as }\end{array}$} & Sortir & - & - & - \\
\hline & Imform & $\sqrt{ }$ & $\sqrt{ }$ & $\sqrt{ }$ \\
\hline & asi & - & $\sqrt{ }$ & $\sqrt{ }$ \\
\hline & $\begin{array}{l}\text { Pembia } \\
\text { yaan } \\
\text { Resiko }\end{array}$ & - & - & - \\
\hline \multicolumn{2}{|c|}{$\begin{array}{r}\text { Keterangan : } \\
- \\
\text { aktivitas }\end{array}$} & \multicolumn{3}{|c|}{$\begin{array}{l}\text { : Melaksanakan aktivits } \\
\text { : Tidak melaksanakan }\end{array}$} \\
\hline & $\stackrel{+}{+}$ & & & \\
\hline
\end{tabular}

\section{Produsen susu kedelai}

Fungsi pertukaran yang di lakukan oleh produsen adalah menjual susu kedelai dan pada umumnya langsung ke konsumen. Produsen dalam menjual susu kedelai cenderung menunggu konsu-men, pedagang pengecer atau grosir yang datang ke rumah, karena produsen lebih mengutaman peker-jaan lain seperti memproduksi susu kedelai. Transaksi jual beli antara produsen dan konsumen dilakuan di rumah produsen.

Fungsi fisik, yang dilakukan oleh produsen adalah melakukan fungsi penyimpanan. Fungsi peyim-panan yang dilakuakan produsen adalah menyimpan susu kedeali ke dalam bok pendingin Fungsi ini dilakukan agar susu kedelai yang telah disiapkan tidak rusak atau tidak layak konsumsi dan dapat di jual ke pedagang grosir, pedagang pengecer maupun langsung ke konsumen.

Fungsi fasilitas yang dilaku-kan oleh produsen susu kedelai ada-lah sortasi 
dan informasi pasar. Produsen melakukan sortasi untuk memastikan bahwa susu kedelai yang di produksi dalam keadaan baik dan layak untuk di konsumsi, sedangkan informasi pasar produsen biasanya mencarai informasi tempat penjualan susu kedelai.

\section{Pedagang Grosir}

Fungsi pertukaran yang dilakukan oleh pedagang grosir yaitu fungsi penjualan dan pembelian. Fungsi ini dilakukan pada setiap pedagang grosir yang menjual susu kedelai. Adapun modal yang diguna-kan adalah modal sendiri dengan membeli susu kedelai yang ditawar-kan oleh produsen dan menyalurkan ke pedagang pegecer .

Fungsi fisik yang dilakukan oleh pedagang grosir yaitu fungsi penyimpanan dan Pengangkutan. Penyimpanan susu kedelai yang dilakukan jika susu kedelai yang dijual tidak terjual habis dalam satu hari dan menyimpannya kembali didalam pendingin dan dijual kembali dikeesokan harinya.

Pedagang grosir melakukan pengangkutan karena pihak produsen tidak mengantarkan susu kedelai melaikan pesagang grosir yang menjemput langsung ke produsen.

Fungsi fasilitas, yang dilaku-kan oleh pedagang grosir adalah fungsi, imformasi, pembia-yaan dan sortasi. Fungsi informasi yang dilakukan pedagang grosir yiatu menghubungi produsen untuk mengetahui keadaan stock susu kedeli di produsen, fungsi pembia-yaan yang di lakukan pedagang grosir yaitu biaya transportasi pengambilan susu kedelai, sedang-kan sortasi yang dilakukan pedagang pengecer adalah pengecekan kema-san susu kedelai yang rusak.

\section{Pedagang Pengecer}

Fungsi pertukaran yang dila-kukan oleh pedagang pengecer yaitu fungsi penjualan dan pembelian. Fungsi penjualan bagi pedagang pengecer yaitu pedgang pengecer harus menjual susu kedelai ke skonsumen, sedangkan pembelian pedagang pengecer melakukan pem-belian susu kedelai di pedagang grosir maupun langsung ke produsen susu kedelai.

Fungsi fisik yang dilakukan oleh pedagang pengecer yaitu fungsi pengangkutan. Fungsi pengangkutan hanya dilakukan pedagang penegcer pada saluran tingkat III saja, dimana pedagang pengecer tersebut menda-tangi pedagang grosir secara lang-sung dan membeli susu kedelai dipedagang grosir dan mengangkat kembali ke tempat penjualan milik pedagang pengecer dan untuk menjualnya lagi kekonsumen.

Fungsi fasilitas, yang dilaku-kan oleh pedagang pengecer adalah fungsi, imformasi, pembiayaan dan sortasi. Fungsi informasi yang dilakukan pedagang pengecer yiatu untuk mengetahui tingkat harga di pedagang grosir dan informasi penjualan susu kedelai ke konsumen, fungsi pembiayan yang di lakukan pedagang pengecer yaitu biaya transportasi pengambilan susu kedelai yang langsung di ambil oleh pedagang pengecer.

\section{Analisis Marjin Pemasaran}

Pada dasarnya adanya perbedaan nilai marjin pemasaran menunjukan perbedaan perlakuan yang diberikan terhadap produk dalam suatu saluran pemasaran. Sehingga pemasaran satu produk bisa menghasilkan nilai marjin pemasaran yang berbeda, semua itu tergantung dari saluran pemasaran yang dipilih dan diperlakuan yang diberikan terhadap produk tersebut.

Marjin pemasaran adalah porsi dari pengeluaran konsumen yang dinikmati oleh lembaga tata-niaga yang meliputi biaya pemasaran dan keuntungan yang diterima oleh lembaga-lembaga pemasaran (Kohls dan Uhl, 2002). Marjin pemasaran dapat digunakan untuk mengetahui harga yang dibayarkan konsumen akhir sampai kepada produsen. Adapun marjin pemasaran susu kedelai Suka Rasa di Desa Pauh Menang Kecamatan Pamenang 
Kabupaten Merangin masing-masing lembaga pemasaran dapat dilihat pada table 2.

Berdasarkan Tabel 2. Dapat dilihat bahwa total marjin pemasaran yang lebih besar terdapat pada saluran III yaitu Rp. $2.500 / \mathrm{bks}$ susu kedelai dan marjin pemasaran yang terendah yaitu terdapat pada saluran I yang tidak memiliki biaya pemasaran disetiap transaksi penjualannya. Dan besarnya marjin pemasaran pada saluran III karena adanya jumlah lembaga pemasaran yang terlibat dalam penyaluran produk dari produsen kekonsumen dan dengan banyaknya lembaga pemasaran yang terlibat. Adapun marjin pemasaran pada lembaga ini adalah pedagang grosir dengan pedagang pengecer. Menurut Daniel (2002), semakin panjang lemabaga yang terlibat maka semakin besar margin pemasarannya.

Pada saluran II total marjin saluran pemasarann berjumlah Rp.1.000/bks dan totalnya lebih kecil dari total marjin dari saluran III karena pada saluran II jumlah lembaga yang terlibat itu sedikit, itu adalah hal yang wajar, karena apabila jumlah lembaga pemasaran yang terlibat itu lebih banyak maka total majin yang diterima itu akan semakin besar (Daniel, 2002).

Menurut Asmarantaka (2012) Setiap keuntungan yang diperoleh oleh suatu lembaga dalam tataniaga dapat dibandingkan dengan lainnya daam satu alur yang sama tanpa adanya perbandingan dengan biaya yang dikeluarkan oleh masing-masing lembaga tersebut. Dan apabila yang diperoleh oleh suatu lembaga tataniaga sangat besar, namun ketika dibandingkan dengan biaya yang dikeluarkan, maka akan terlihat bahwa lembaga tersebut mengambil keuntungan dengan yang terlihat sama dengan lembaga lainnya.

Tabel 2. Analisis Pemasaran Susu Kedelai Suka Rasa Di Desa Pauh Menang Kecamatan Pamenang Kabupaten Merangin Tahun 2020

\begin{tabular}{|c|c|c|c|}
\hline \multirow{2}{*}{$\begin{array}{c}\text { Lembaga Pemasaran Dan Unsur } \\
\text { Pemasaran }\end{array}$} & \multicolumn{3}{|c|}{ Pola Saluran Pemasaran } \\
\hline & I & II & III \\
\hline \multicolumn{4}{|l|}{ Produsen } \\
\hline Harga jual & 1.500 & 1.500 & 1.500 \\
\hline Biaya pemasaran & - & - & - \\
\hline \multicolumn{4}{|l|}{ Pedagang Grosir } \\
\hline Harga Beli (Rp/bks) & - & - & 1.500 \\
\hline Harga Jual (Rp/bks) & - & - & 2.500 \\
\hline Marjin Pemasaran (Rp/bks) & - & - & 1.000 \\
\hline Biaya pemasaran (Rp/bks) & - & - & 194 \\
\hline Keuntungan (Rp/bks) & - & - & 806 \\
\hline \multicolumn{4}{|l|}{ Pedagang Pengecer } \\
\hline Harga Beli (Rp/bks) & - & 1.500 & 2.000 \\
\hline Harga Jual (Rp/bks) & - & 2.500 & 3.000 \\
\hline Marjin Pemasaran (Rp/bks) & - & 1.000 & 1.500 \\
\hline Biaya pemasaran (Rp/bks) & - & 203 & 175 \\
\hline Keuntungan (Rp/bks) & - & 797 & 1.325 \\
\hline Total Biaya Pemasaran (Rp/bks) & - & 203 & 369 \\
\hline Total Keuntungan & - & 797 & 2.131 \\
\hline Total Majin Pemasaran & - & 1.000 & 2.500 \\
\hline
\end{tabular}


Salah satu indikator yang berguna dalam melihat efisiensi operasional dalam kegiatan tataniaga adalah dengan menghitung bagian yang diterima oleh petani (farmer's share). Menurut Asmarantaka (2012) Farmer's share merupakan perbandingan persentase harga yang diterima oleh petani dengan harga yang dibayar di tingkat konsumen akhir. Farmer's share mempunyai nilai yang relatif rendah jika harga di tingkat konsumen akhir relatif lebih tinggi dibanding harga yang diterima oleh petani. Sebaliknya, farmer's share mempunyai nilai yang relatif lebih tinggi jika harga di tingkat konsumen akhir tidak terpaut jauh dibanding harga yang diterima oleh petani. Adapun Farmer's share pemasaran susu kedelai Suka Rasa Di Desa Pauh Menang Kecamatan Pamenang Kabupaten Merangin dapat dilihat pada Table 3.

Tabel 3. Farmer's Share Pada Pola Saluran Pemasaran Susu Kedelai Suka Rasa Di Desa Pauh Menang Kecamatan Pamenang Kabupaten Merangin. 2020

\begin{tabular}{cccc}
\hline $\begin{array}{c}\text { Pola } \\
\text { Salura } \\
\mathrm{n} \\
\begin{array}{c}\text { Pemsar } \\
\text { an }\end{array}\end{array}$ & $\begin{array}{c}\text { Harga jual } \\
\text { di tingkat } \\
\text { produsen } \\
\text { (Rp/bungk } \\
\text { us) }\end{array}$ & $\begin{array}{c}\text { Harga jual } \\
\text { Ditingkat } \\
\text { konsumen } \\
\text { akhir } \\
\text { (Rp/bungk } \\
\text { us) }\end{array}$ & $\begin{array}{c}\text { Farme } \\
\text { Share } \\
(\%)\end{array}$ \\
\hline I & 1.500 & 1.500 & 100 \\
II & 1.500 & 2.500 & 60 \\
III & 1.500 & 3.000 & 50 \\
\hline
\end{tabular}

Sumber : Data Olahan Penelitian, 2020

Berdasarkan Tabel 3 Dapat dilihat bahwa farmer's share tertinggi adalah pada saluran pemasaran I dengan nilai farmer's share sebesar 100\%. Sedangkan yang terendah berada pada saluran pemasaran ke III dengan nilai farmer's share $50 \%$ dan saluran pemasaran II dengan jumlah nilai farmer's share $60 \%$.
Jika dilihat dari nilai farmer's share yang dilihat pada tabel 3 maka pemasaran Susu Kedelai Di Desa Pauh Menang Kecamatan Pamenang Kabupaten Merangin ini sudah efisien karena menyatakan bahwa presentase yang diterima oleh petani dari harga yang dibayarkan oleh konsumen akhir dikatakan efisien itu lebih besar dari 50\% dan tidak efisien jika di bawah $50 \%$.

\section{Efisiensi Pemasaran}

Menurut Mubyarto (1995), sistem pemasaran dianggap efisien apabila mampu menyampaikan hasil-hasil dari produsen kepada konsumen dengan biaya wajar serta mampu mengadakan pembagian yang adil dari keseluruhan yang di bayar konsumen. Efisiensi pemasaran juga dapat dilihat dari panjang pendeknya saluran pemasaran susu kedelai. Semakin pajang saluran pemasaran yang dilewati maka semakin banyak lembaga pemasaran yang terlibat, maka semakin besar pula nilai efisiensi sebuah pemasaran. Adapun data hasil olahan penelitian untuk melihat efisiensi pemasaran pada susu kedelai Suka Rasa Di Desa Pauh Menang Kecamatan Pamenang Kabupaten Merangin dapat dilihat pada Tabel 4.

Tabel 4. Nilai Efisiensi Pemasaran Pada Pola Saluran Pemasaran Susu Kedelai Di Desa Pauh Menang Kecamatan Pamenang 2020

\begin{tabular}{|c|c|c|c|}
\hline $\begin{array}{l}\text { Pola } \\
\text { Saluran } \\
\text { Pemsar } \\
\text { an }\end{array}$ & $\begin{array}{l}\text { Harga jual } \\
\text { di tingkat } \\
\text { konsumen } \\
\text { (Rp/bungk } \\
\text { us) }\end{array}$ & $\begin{array}{c}\text { Marjin } \\
\text { pemasaran } \\
\text { (Rp/bungk } \\
\text { us) }\end{array}$ & $\begin{array}{c}\text { Efisie } \\
\text { nsi } \\
(\%)\end{array}$ \\
\hline I & 1.500 & 0 & 0,0 \\
\hline II & 2.500 & 1.000 & 40 \\
\hline III & 3.000 & 2.500 & 83,3 \\
\hline
\end{tabular}

Sumber : Data Olahan Penelitian, 2020

Berdasarkan Tabel 4 dapat dilihat bahwa saluaran pemasaran I merupakan 
pola saluran pemasaran yang efisien karena efisiensi yang paling rendah yaitu $0 \%$ dan dapat dikuti dengan saluran II yaitu sebesar $40 \%$ dan pada saluran pemasaran III dengan nilai efisiensi pemasaran 83,3\% Besarnya nilai efisiensi pada saluran III ini dikarenakan terdapat banyaknya lembaga pemasaran yang terlibat sehingga pada saluran pemasaran III ini kurang efisien. Pada penelitian (Abhar, dkk. 2018) bahwa persentase pada pemasaran kentang dibawah 50\% ini menunjukkan efisiensi dari suatu pemasaran sehingg semakin rendah atau kecilnya persentase efisiensi sebuah pemasaran maka pemasaran semakin efisien, sabaliknya, semakin tinggi persentase efisiensi sebuah pemasa-ran maka pemasaran semakin tidak efisien (Soekartawi, 2002).

\section{Kesimpulan dan Saran Kesimpulan}

Berdasarkan hasil Penelitian, maka dapat diambil kesimpulan sebagai berikut:

1. Pola pemasaran susu kedelai Suka Rasa Di Desa Pauh Menang Kecamatan Pamenang Kabupaten Merangin terdiri dari 3 pola saluran pemasaran yaitu dimana : Saluran I : Produsen $\rightarrow$ Konsumen, Saluran II : Produsen $\rightarrow$ Pedagang Pengecer $\rightarrow$ Konsumen, Saluran III : Produsen $\rightarrow$ Pedagang Grosir $\rightarrow$ Pedagang Pengecer $\rightarrow$ Konsumen.

2. Pada fungsi pemasaran yang dilakukan oleh setiap lembaga pemasaran susu kedelai suka rasa meliputi fungsi pertukaran, fungsi fisik dan fasilitas.

3. Saluran pemasaran susu kedelai Suka Rasa Di Desa Pauh Menang Kecamatan Pamenang Kabupaten Merangin sudah efisien karena hasil perhitungan pada saluran pemasaran I, II dan III memiliki nilai sebagai berikut :

- Pada saluran I memiliki nilai marjin pemasaran $\mathrm{Rp}$. 0 , nilai farmer's share $100 \%$ dan efisensi pemasaran nya $0 \%$

- Pada saluran II memiliki nilai marjin pemasaran Rp. 1.000 , nilai farmer's share $60 \%$ dan efisensi pemasaran nya $40 \%$

- Pada saluran III memiliki nilai marjin pemasaran Rp. 2.500, nilai farmer's share $50 \%$ dan efisensi pemasaran nya $83,3 \%$

\section{Saran}

Berdasarkan hasil penelitian ini maka disarankan kepada pihak produsen susu kedelai Suka Rasa di Desa Pauh Menang Kecamatan Pamenang Kabupaten Merangin disarankan untuk meningkatkan kemasan susu kedelai dengan kemasan botol agar lebih menarik konsumen di pasaran, serta mencari-kan pekerja, pekerja yang dimaksud seperti pengecer susu kedelai ke setiap warung atau toko dengan begitu masyarakat Kabupaten Mera-ngin lebih terjangkau dalam pembelian susu kedelai suka rasa pak Bakrun, dan mampu meningkatkan produksi susu kedelai.

\section{Daftar Pustaka}

Abhar, E., Isyaturriyadhah, I., \& Fikriman, Kabupaten Merangin. JAS (Jurnal Agri Sains), 2(1).

Asmarantaka RW. 2012. Pemasaran Agribisnis (Agrimarketing). Bogor (ID) : IPB

Cahyadi W. 2012. Bahan tambahan pangan : Bumi Aksara. Jakarta

Daniel, M, 2002. Pengantar Ekonomi Pertanian. Penerbit Bumi Aksara. Jakarta Dinas Perindustrian Kabupaten Merangin 2017

Dinas Tanaman Pangan dan Horti-kultura. 2018 Kabupaten Merangin.

Fikriman, F. (2017). Tranformasi Pertanian dan Pembangunan Pedesaan. JAS (Jurnal Agri Sains), 1(2).

Masyhuri. M. 2011. Teori Ekonomi mikro. PT. Refika Aditama. Bandung. 
Mubyarto. 1994. Pengantar Ekonomi Pertanian. LP3ES. Jakarta.

Musrid. M 1997. Manajemen Pemasaran. Aksara Bekerja-sama Antar Universitas Studi Ekonomi. Jakarta Solahuddin. A. 2011. Pemasaran Pertanian. UMM Press. Malang.

Sudiyono, A. 2004. Pemasaran pertanian. UMM Press. Malang.

Sugiyono, (2008). Metode Penelitian Kunatitatif Kualitatif dan R\&D. Alfabeta. Bandung
Sugiyono. 2013. Metode Penelitian Pendidikan Pendekatan Kuantitatif, Kualitatif, dan R\&D: Alfabeta. Bandung

Suparmoko. 2011. Dasar - Dasar Agroindustri. Penerbit Swadaya. Jakarta.

Suprapti L. 2003. Pembuatan Tempe. Kanisius. Yogyakarta

Yorin. M. 2009. Dasar - Dasar Agroindustri. Pustaka Sinar Harapan. Jakarta. 